\title{
Rapid Chemical Tests in the Autopsy Room
}

\author{
BIANCA HANGANU ${ }^{1}$, ANDREEA ALEXANDRA HLESCU1,2*, IRINA SMARANDA MANOILESCU1,2*, ANDREEA ELENA BIRLESCU1,2, \\ VALENTIN PETRE CIUDIN ${ }^{1,2}$, CRISTINA DIMITRIU³, CAMELIA LIANA BUHAS ${ }^{4,5 *}$, MIHAELA CRISTINA SOMLEA ${ }^{6}$, \\ BEATRICE GABRIELA IOAN ${ }^{1,2}$ \\ ${ }^{1}$ Grigore T. Popa University of Medicine and Pharmacy, Discipline of Legal Medicine, 16 Universitatii Str., 700115, Iasi, Romania \\ IInstitute of Legal Medicine, 4 Buna Vestire Str., 700455, Iasi, Romania \\ ${ }^{3}$ Grigore T. Popa University of Medicine and Pharmacy, Discipline of Biochemistry, 16 Universitatii Str., 700115, lasi, Romania \\ ${ }^{4}$ Oradea University, Faculty of Medicine and Pharmacy, Department of Morphological Disciplines, 1 Universitatii Str., 410087, \\ Oradea, Romania \\ ${ }^{5}$ Bihor County Forensic Service, 50 Calea Clujului, 410053, Oradea, Romania \\ ${ }^{6}$ County Clinic Emergency Hospital, Dermatovenerology Clinics, 3-5 Clinicilor Str.,400000, Cluj-Napoca, Cluj, Romania
}

\begin{abstract}
From its beginning, the autopsy represented a useful instrumentfor the progression of medicine and continues to be a valuable tool in postmortem diagnosis of various diseases or traumatic injuries. Modern laboratory technology is an important aid in achieving autopsy goals but it is either not available or not permanently available in all the departments of Forensic Medicine and do not offer every time quick results, which might be necessary to guide the next steps of the forensic investigation. In this paper the authors present a set of rapid, sensitive and effective chemical reactions, described in the literature over the time and meant to support the forensic experts, as they can be easily performed in the autopsy room. Moreover, the application of these reactions may reduce the costs of laboratory analyzes in cases where the use of expensive laboratory technologies is no longer required or limited by the results of these reactions. Also, a brief description of the collection method for biological samples to be used is provided. At the end of the paper the authors suggest a minimum kit of chemical substances which are necessary in the autopsy room, in order for these analyses to be performed.
\end{abstract}

Keywords: autopsy, chemistry, reactions, diagnosis, forensics

Over the time, autopsy has been an important tool for the evolution of medicine through its essential contribution to the knowledge of human anatomy and physiology, of the etiology of various diseases and the discovery of numerous therapeutic methods [1, 2].

Despite the technologic progress made in the medical field, especially regarding the diagnostic possibilities, such as modern imaging techniques, autopsy remains a valuable tool in postmortem diagnosis of various diseases or traumatic injuries [3-6].

In the same time, autopsy represents a useful audit tool in clinical settings $[2,7-13]$, which contributes in a significant way to the progress of medicine and improvement of current medical practice, as well as to the medical education in universities [14, 15].

In Romania, the forensic autopsy is performed by forensic pathology experts, in certain circumstances well defined by the law and it is requested by the investigative bodies, regardless the consent of the family of the deceased [16].

The aim of the forensic autopsy is mainly determination of the cause of death and mechanism leading to death. Many times the gross examination of the body must be supplemented by laboratory analyses, all together leading to clarification of the various aspects in medico-legal cases. Modern laboratory technology has numerous advantages, adds more precision to the forensic activity [17], being an important aid in achieving the autopsy goals but it is either not available or not permanently available in all the Forensic Medicine departments and do not offer every time quick results, which might be necessary to guide the next steps of the forensic investigation.

\section{Experimental part \\ Materials and methods}

The aim of this paper is to describe and analyze a series of rapid, sensitive and effective chemical reactions, which might be used for the preliminary diagnosis in the autopsy room. For this purpose, research of the specialized literature has been carried out to identify those chemical reactions that can be performed by people with minimal chemistry training and which provide quick results using minimal, low expensive resources that can lead to additional cost reductions for institutions by decreasing the number of unnecessary laboratory tests. In this way, the paper represents a valuable tool for the forensic pathologist who faces diagnostic dilemmas during autopsy and who must decide either to establish a diagnosis of death after autopsy, or to collect biological samples for laboratory examinations, or the laboratory examinations he/she has to ask for.

Although the degree of specificity of these reactions is not always high, positive results are of use to the forensic pathologist because they may indicate the need for additional laboratory examinations. Through these tests, the presence of the suspected item can be demonstrated or ruled out $[18,19]$. As a way of verifying the correctness of the application of the method and avoiding traps, tests on the samples to be analyzed must be accompanied by control tests, i.e. a negative blank and a positive control $[18,20]$.

Sample collection should be performed using clean or sterile instruments.

Vitreous humour is collected by ophtalmocentesis. The needle of the syringe is inserted in the lateral corner of the eye, with an oblique direction towards the center of the

\footnotetext{
*email: andreea.velnic@yahoo.com manoilescuirina@yahoo.com cameliabuhas@yahoo.com
} 
eye. The aspiration is performed gently, this allowing collection of the fluid without detaching the retinal cells [21, 22].

Peripheral blood can be collected from the femoral vein by incision of the skin or by puncture of the vessel using a syringe with large-bore needle [22].

Urine can be collected either before opening the body by puncture of the urinary bladder through the abdominal wall above the pubic symphysis or after opening the abdominal cavity by direct puncture of the urinary bladder wall [21].

Gastric content is collected after clamping the stomach at both ends- above the cardia and bellow the pylorus. The stomach is then removed and the wall is cut, allowing collecting its content [21].

Pericardial fluid is collected by aspiration with a syringe immediately after removing the anterior wall of the chest and opening the pericardial sac with a scissor close to the apex [23].

\section{Results and discussions}

Preliminary toxicological tests in the autopsy room

In order to establish a correct diagnosis and to guide the laboratory toxicological analysis to the most appropriate direction, it is necessary for the forensic pathologist to take into accountall the information available in the case history, regarding the clinical findings prior to victim's death, all the details gathered during autopsy, so as to achieve the most correctassociations of ante mortem and postmortem changes. Especially in the case of intoxication, it is necessary to carefully examine the gastrointestinal tract, liver, kidneys, lungs and blood. The odor and particular color of the contents of the gastrointestinal tract may prove very useful as well [20].

Additionally, the orientation of the toxicological examination on the basis of preliminary positive reactions in the autopsy room could shorten the time required for the laboratory toxicological examination as well as its costs [18]. A preliminary exam for detecting the most common toxic substances is often useful in case of sudden deaths [20].

\section{Cyanide screening test}

The diagnosis of hydrogen cyanide poisoning is suggested on the one hand by the organoleptic characteristics of the toxic, i.e. the specific odor of bitter almonds, and on the other hand by the particular reddish color of the cadaveric lividity [18].

Hydrogen cyanide poisoning may also be demonstrated in the autopsy room by analyzing the gastric content or blood collected from the corpse using several methods:

a. The first method is based on the chemical reaction between hydrogen cyanide and sodium (potassium) carbonate in picric acid medium:

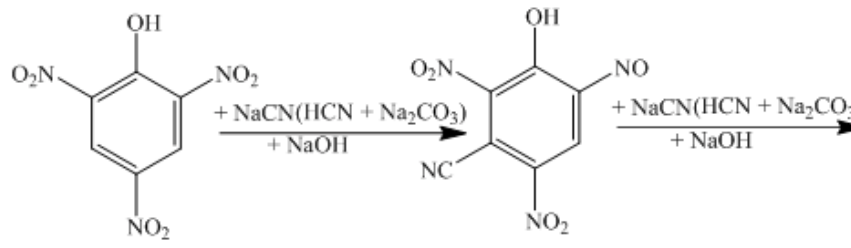

\section{Working method}

A strip of filter paper is introduced into saturated picric acid. Few drops of the biological sample to be analyzed (gastric content, blood) are then added on the paper. The sample is left to dry for a few moments, then a drop of $10 \%$ sodium carbonate must be added. The reaction is positive for cyanides if a red-violet color appears, which tends to become more blue as the concentration of the cyanide is higher [24].

The reaction may give false positive results in case of large quantities of sulfide being present in the biological samples [24].

b. The second method is based on the reaction of cyanmethemoglobin formation.

\section{Working method}

A strip of filter paper is soaked in normal blood, and then potassium chloride is added. Following this reaction, methemoglobin will be formed. The next step is to place the filter paper in the analyzing sample (gastric content, blood, pulmonary edema fluid). In the presence of hydrogen cyanide, methemoglobin will turn into cyan-methemoglobin, which will color the filter paper in red [24].

\section{Carbon monoxide test}

Carbon monoxide is a toxic substance that has been harmful to the human beings since they first made the fire in the caves. Carbon monoxide poisoning is particularly dangerous, especially as there are many sources of poisoning, such as: exhaust gases, household devices, structural fires, various industrial processes, incomplete combustion of the coal $[25,26]$.

In general, death occurs at moderate to high concentrations of carbon monoxide in the breathing air and, implicitly, moderate to high concentrations of carboxyhemoglobin (COHb) in the blood. However, death may also occur at low concentrations in the case of alcohol consumption or sedation prior to exposure to carbon monoxide, as well as in people with cardiac or pulmonary diseases (e.g., atherosclerotic heart disease, chronic pulmonary disease, emphysema) [24].

The toxic effects of carbon monoxide are due both to hypoxia- by oxygen replacement on hemoglobin (transportation anoxia) and to its effect at cellular level-by blocking myoglobin or enzymes in the cytochrome group [25].

Carboxyhemoglobin and carboxymioglobin will determine a reddish-pink coloration to the blood and, implicitly, to the muscles and organs. This particular staining, how ever, occurs only when carboxyhemoglobin concentration is greater than $33 \%$. The reddish-pink color of the blood, although a valuable element for establishing the diagnosis of death by carbon monoxide intoxication, may also occur for example in the case of hypothermia or cyanide intoxication $[24,25]$, thus being necessary to establish with certainty which is the causative agent. 


\section{Working method}

The method of detecting $\mathrm{COHb}$ in the cadaveric blood in the autopsy room consists of adding a few drops of $10 \%$ sodium hydroxide solution into a tube containing the blood sample and observing the color changes.

The method is based on the fact that hemoglobin in normal blood will turn into methemoglobin in the presence of $10 \%$ sodium hydroxide, the sample being colored in brownish-green, according to the following reaction:

$$
\mathrm{COHb}\left(\mathrm{Fe}^{2+}\right) \stackrel{\mathrm{NaOH}}{\longrightarrow} \text { Methemoglobin }\left(\mathrm{F}^{3+}\right)
$$

This test is applicable in adult red cells which contain $\mathrm{HbA}$; the fetal hemoglobin- $\mathrm{HbF}$ being resistant to alkali denaturation (the alkali denaturation test).

Presence of carbon monoxide prevents formation of methemoglobin, allowing the color of the biological sample to remain pink [25].

\section{Ketone detection test}

The analysis of blood, pericardial fluid, vitreous humor, and urine can provide indications about the presence of ketonic substances (acetone, acetoacetate, bhydroxybutyrate), allowing also to measure them quantitatively [22].

The presence of ketoacidosis can be detected by the utilization of dipstick tests of urine, which enable a quick detection [17].

\section{a. Nitroprusside test}

The strips contain sodium nitroprusside which in alkaline medium reacts with acetoacetate or acetone to form a purple-colored compound according to the following reaction [27].

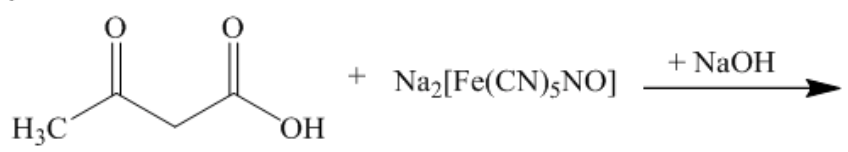

$$
\stackrel{\mathrm{NaOH}}{\longrightarrow} \begin{gathered}
\text { Purple-colored } \\
\text { compound }
\end{gathered}
$$

The intensity of the color is directly proportional to the amount of ketonic substances in the analyzed biological sample and can be estimated by the color scale.

b. Enzymatic methods measure the concentration of the enantiomer D-Beta hydroxybutyrate in plasma. The enzyme Beta-hydroxybutyrate dehydrogenase ( $\beta$-HBD) catalyzes the oxidation of D-Beta-hydroxybutyrate to acetoacetate. Concomitant with this oxidation the cofactor NAD+ is reduced to NADH and the associated change of absorbance can be correlated with the D-Betahydroxybutyrate concentration. D-Beta-hydroxybutyrate in the blood specimen reacts with NAD in the presence of $\beta$ HBD.

$$
\begin{aligned}
& \mathrm{NADH}+\mathrm{H}+\text { acetoacetic acid } \underset{\beta-\mathrm{HBD}}{\stackrel{\mathrm{HBD}}{\longrightarrow} \mathrm{NAD}+\beta \text {-hydroxybutyric acid }}
\end{aligned}
$$

This method uses special strips (Ketone Test Strips), which are useful in determinations in serum [28].

\section{Detection of lipids (fatty changes)}

The reaction for the detection of lipids may prove useful for the delimitation of malignant lesions infiltrating the tissues $[24,29]$ or to demonstrate various fatty changes in the tissues: differential diagnosis of fatty liver dystrophy with cadaveric color changes and consistence changes (yellow spots, clay like appearance) [30], pancreatic lipomatosis [31].

Fresh or formaldehyde fixed specimens are immersed in Scharlach R or Sudan III saturated solution in 70\% alcohol. The fat will turn bright red.

Discoloration of non-fatty tissues is done by placing specimens in alcohol 95\% [24].

\section{Acute myocardial infarction/ischemia}

Microscopic and macroscopic changes in myocardial ischemia can be identified after a few hours after its occurrence, making postmortem detection of acute myocardial infarction follow ed by rapid/immediate death almost impossible. The lack of typical macroscopic expression of acute myocardial infarction within the first 6-8 $\mathrm{h}$ after its occurrence also makes it unlikely to collect suitable specimens for microscopic examination. Likewise, early postmortem detection of acute myocardial infarction by dosing of necrosis enzymes is questionable and largely influenced by several variables, including the application of cardiopulmonary resuscitation maneuvers.

It is possible to identify the myocardial infarction/ ischemia area in the autopsy room with tetrazolium salts, which will determine various discolorations to the myocardium.

Among the most commonly used salts are nitro-bluetetrazolium (NBT) and triphenyl tetrazolium chloride (TIC) [24].

\section{Working method}

In order to detect myocardic infarction within the first 5 to $10 \mathrm{~h}$ of its occurrence using tetrazolium salts, crosssectional heart sections are embrocated with triphenyl tetrazolium chloride (TTC). The activity of tissue dehydrogenase in the normal myocardium will reduce TTC to red formazan, coloring the myocardium accordingly [25, 32] as per to the reaction below, while the infarct areas will remain uncolored $[25,32]$ as a result of its lack of activity.
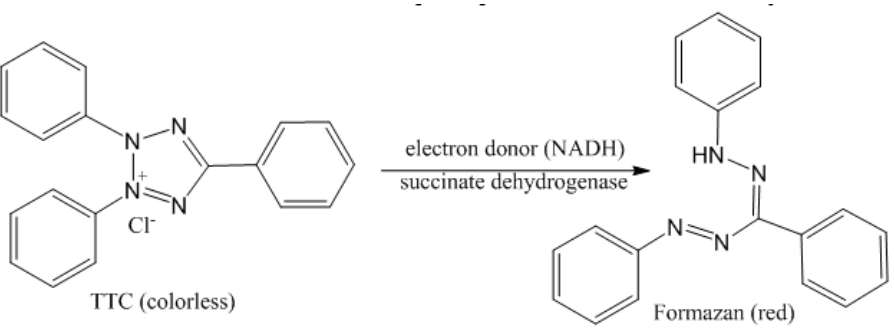

Nachlas and Shnitka (1963) used nitro-blue tetrazolium (NBT) to color the heart fragments, obtaining a clearer delimitation between healthy myocardium - colored and necrotic myocardium - uncolored. Likewise, the use of NBT salts also allows the estimation of the extent of the infarcted area [32].

The explanations for this delimitation between the normal myocardium and the ischemic myocardium are divided: Sandritter and Jestadt (1958) account for the decrease of dehydrogenase activity, while Nachlas and Shnitka (1963) consider that the changes in the recent stages are determined by the loss of coenzyme and substrate, and those in the final stage by the loss of respiratory coenzymes [32].

In the case of relative myocardial ischemia, following the hypertrophy of the myocardial fibers $[33,34]$, the enzymatic activity will be reduced and the area will appear pale after embrocation with tetrazolium [25]. 
Detection of blood in biological samples

Methods for detecting blood in biological samples are based on the chemical reaction of oxidation of a chromogen by an oxidizing agent (usually $3 \%$ hydrogen peroxide) catalyzed by the presence of hemoglobin in the sample to be analyzed. Depending on the type of chromogen, the presence of blood is detected by characteristic color changes. False positive results may also occur, but these will be demonstrated by highlighting the color changes in the absence of the oxidizing agent [35]. False positive results may occur in the presence of the following compounds: chemical oxidants (color changes occur before combining with peroxide), vegetal products (vegetable peroxidases are thermolabile and can be destroyed by careful heating), animal products (which are not pure blood but contain contaminants of blood) [35]. These features make the chemical tests for blood detection sensitive, but unspecific [36].

\section{Detection of blood in gastro-intestinal content}

Detecting blood in gastrointestinal content in the autopsy room is essential in situations where blood can be confused with the ingestion of certain solid or liquid foods with reddish-blackish coloring [37].

\section{Adler test - benzidine test}

Principle of the method: benzidine as a leuco derivative (colorless) is oxidized due to the peroxidase action of hemoglobin in the presence of hydrogen peroxide in an acid medium to a colored quinoidine compound.

\section{Working method}

1-2 $\mathrm{mL}$ of gastric content is mixed with 15-20 pure benzidine crystals and 5-10 drops of glacial acetic acid. It is mixed well, adding a few drops of $3 \%$ hydrogen peroxide. In the presence of blood, there is a green or blue color of intensity directly proportional to the amount of hemoglobin contained in the gastric content. Although it is a fast method, it is extremely rarely used due to the carcinogenic potential of benzidine [37].

\section{Guaiac test}

Guaiac is a chemical derived from a tree resin. The principle of the chemical tests to detect blood is based on the fact thathemoglobin and its derivatives react in a similar way to peroxidase enzymes- by catalyzing the transfer of an oxygen atom from the peroxide to a chromogen such as benzidine, o-toludine, guaiac or aminophenazone. Oxidation of the chromogen is indicated by the appearance of a blue, blue-green or pink color. A simplified reaction equation is shown below:

$$
\underset{\text { (colorless) }}{\mathrm{Guaiac}}+\quad \mathrm{H}_{2} \mathrm{O}_{2} \stackrel{\text { Hemoglobin }}{\longrightarrow} \quad \begin{gathered}
\text { "Oxidized" Guaiac } \\
\text { (blue color) }
\end{gathered}
$$

\section{Working method}

The test is performed on a paper sheet that contains paper squares coated with guaiac. Few drops (3-5) of the biologic specimen are applied to the paper. A developer solution containing hydrogen peroxide $\left(\mathrm{H}_{2} \mathrm{O} 2\right)$ is added to the paper. If the blood is present in the specimen, the iron $(\mathrm{Fe})$ in hemoglobin catalyzes the reaction between guaiac in the paper and $\mathrm{H} 2 \mathrm{O} 2$. The completed reaction forms a blue color [38].

\section{Differentiation of exudate from transudate- Rivalta test Principle of the method}

The method is based on the reaction of certain protein structures with acetic acid. There are 8 types of proteins that give a positive Rivalta test (C-reactive protein, haptoglobin, transferrin, ceruloplasmin, fibrinogen, hemopexin, alpha 1-antitrypsin, and alpha 1-acid glycoprotein or AGP).

\section{Working method}

To perform this test, a transparent reagent tube (volume $10 \mathrm{~mL}$ ) is filled with approximately 7-8 $\mathrm{mL}$ distilled water, to which 1 drop of acetic acid (98\%) is added and mixed thoroughly. On the surface of this solution, 1 drop of the pleural fluid is carefully layered.

If the drop disappears and the solution remains clear, the Rivalta test is defined as negative. If the drop retains its shape, stays attached to the surface or slowly floats down to the bottom of the tube (drop-or jelly-fish-like), the Rivalta test is defined as positive.

A positive Rivalta test may suggest an inflammation, indicating an exudate. A negative Rivalta test indicates a transudate [39].

\section{Differential diagnosis of air and putrefaction gases - the} Pyrogallol Test

The presence of putrefaction process can prevent or make it difficult to detect gas

embolism at autopsy.

One method by which putrefaction gases can be differentiated from air is the pyrogallol test.

\section{Working method}

The test uses a $2 \%$ pyrogallol solution, from which $4 \mathrm{~mL}$ are extracted in 2 syringes of $10 \mathrm{~mL}$ each, preventing the air from entering inside. Subsequently, in the first syringe, 4 drops (one drop per $\mathrm{ml}$ of solution) of $0.5 \mathrm{~N}$ sodium

\begin{tabular}{|c|c|}
\hline SUBSTANCE & TEST \\
\hline Saturated picric acid & \multirow[t]{3}{*}{ Cyanide screening test } \\
\hline $10 \%$ Sodium carbonate & \\
\hline $\mathrm{KCl} 2 \mathrm{M}$ & \\
\hline $10 \%$ Sodium hydroxide & Carbon monoxide test \\
\hline Urine dipstick test & Ketones in urine \\
\hline Ketone Test Strips & Ketones in serum \\
\hline $3 \%$ Hydrogen peroxide & \multirow[t]{2}{*}{ Detection of blood } \\
\hline Benzidine & \\
\hline Acetic acid $(98 \%)$ & Rivalta test \\
\hline Pyrogallo $12 \%$ & \multirow[t]{2}{*}{ Air vs. putrefaction gases } \\
\hline $0.5 \mathrm{~N}$ Sodium hydroxide & \\
\hline Nitro-blue tetrazolium (NBT) & Acute myocardial infarction \\
\hline $\begin{array}{l}\text { Scharlach R or Sudan III saturated solution in } \\
70 \% \text { alcohol }\end{array}$ & Fatty changes \\
\hline
\end{tabular}
(potassium) hydroxide are aspirated so that the mixture will reach a pH of 8 and the color will be yellowish pale. 
After the preparation of the mixture, $6 \mathrm{~mL}$ of gas from the heart or blood vessels are aspirated, the needle is sealed and the syringe is shaken vigorously for $1 \mathrm{~min}$. The difference between the air and the putrefaction gases is made by the appearance of a dark brown color in the first case and the lack of color changes in the second. In order to verify the correctness of the test, room air can be drawn as a control sample [24].

The minimum kit required in the autopsy room

Based on the results of our study, we propose a minimum kit with chemical substances that can find its usefulness in currentautopsy activity by facilitating the rapid diagnosis of the lesion or of the cause of death, as well as by directing the forensic pathologist to collect the most appropriate samples for additional laboratory tests (table 1).

\section{Conclusions}

Autopsy has been and remains an important tool in medical practice for the elucidation of various pathologies or causes of traumatic injuries. Modern laboratory technology have strongly influenced the forensic practice in terms of increasing accuracy and diagnostic possibilities. However, modern technology is either not available or not permanently available in all the departments of Forensic Medicine and do not offer every time quick results, which might be necessary to guide the next steps of the forensic investigation.

The chemical reactions described in this paper answer the forensic pathologist's need to decide on the cause of death, the biological samples he/she will harvest for more in-depth laboratory analyzes and further laboratory analysis to be required. These are all the more important as there are forensic institutions that do not benefit from the permanent support of specialized laboratories. Moreover, the application of these rapid, inexpensive chemical tests may reduce the costs of the laboratory analyzes in cases where the use of expensive laboratory technologies is no longer required or limited by the results of these reactions.

\section{References}

1.HILL, R.B., ANDERSON, R.E. The autopsy- medical practice and public policy. Stoneham, MA: Butterworth Publishers, 1988.

2.IOAN, B., ALEXA, T., ALEXA, I. Rom. J. Leg. Med., 20, no. 4, 2012, p. 307.

3.JUDEA-PUSTA, C.T., MUTIU, G., PASCALAU, A.V., BUHAS, C.L., CIURSAS, A.N., NISTOR-CSEPPENTO, C.D., BODEA, A., JUDEA, A.S., VICAS, R.M., DOBJ ANSCHI, L., POP, O.L. Rom. J. Morphol. Embryol., 59, no. 3, 2018, p. 965.

4.BUHAS, C., MIHALACHE, G., BUHAS, B., BUNGAU, S. Rom. J. Leg. Med., 24, no. 4, 2016, p. 300.

5.PUSTA, C.T., MIHALACHE, G., BUHAS, C., POP, O. Rom. J. Leg. Med., 23, no. 4, 2015, p. 247.

6.PETRE-CIUDIN, V., HANGANU, B., VELNIC, A.A., IOAN, B.G. Forensic Sci. Int., 277, (Suppl. 1), 2017, p. 220.

7.SPILIOPOULOU, C., PAPADODIMA, S., KOTAKIDIS, N., KOUTSELINIS, A. Arch. Pathol. Lab. Med., 129, 2005, p. 210.

8.BATTLE, R.M., PATHAK, D., HUMBLE, G., KEY, C.R., VANATTA, P.R., HILL, R.B., ANDERSON, R.E. J. Am. Med. AssoC., 258, no. 3, 1987, p. 339.

9.LANDEFELD, C.S., CHREN, M.M., MYERS, A., GELLER, R., ROBBINS, S., GOLDMAN, L. N. Engl. J. Med., 318, no. 19, 1988, p. 1249. 10.ERMENC, B. J. Forensic Sci., 44, no. 4, 1999, p. 810.

11.PAKIS, I., POLAT, O.G., YAYCI, N., KARAPIRLI, M. Am. J. Forensic Med. Path., 3, 2010, p. 218.
12.IOAN, B.G., ALEXA, T., ALEXA, I. Rom. J . Leg. Med., 22, no. 2, 2014, p. 127.

13.VELNIC, A.A., HANGANU, B., PETRE CIUDIN, V., CRAUCIUC, D., MANOILESCU, I.S., IOAN, B.G. Rom. Neurosurg., 31, no. 4, 2017, p. 455.

14.IOAN, B., NEAGU, M., MANOILESCU, I., PLAIESU, T., DAMIAN, $S$. Rev. Med. Chir. Soc. Med. Nat. Iasi, 118, no. 3, 2014, p. 801.

15.MANOILESCU, I.S., HANGANU, B., VELNIC, A.A., IOAN B.G., IORGA, M. Rom. J. Leg. Med., 25, no. 4, 2017, p. 439.

16.*** Ordonanta Guvernului nr. 1/2000 privind organizarea activitatii si functionarea institutiilor de medicina legala (Government Ordonance no. 1/2000 on the organization of the activity and the functioning of the legal medicine facilities). Available at www.cdep.ro. 17.HANGANU, B., VELNIC, A.A., MANOILESCU, I.S., IOAN, B.G. Postmodern Openings, 8, no. 3, 2017, p. 12.

18.BADCOCK, N. Ann. Clin. Biochem., 37, 2003, p. 146

19.BARTOS D, DIACONU C, BADILA E, DARABAN AM. Farmacia, 62, no. 5,2014, p. 811-823.

20.KAYE, S. Laboratory Medicine, 3, no. 5, 1972, p. 28

21.DINIS-OLIVEIRA, R.J., VIEIRA, D.N., MAGALHÃES, T. Forensic Sci. Res., 1, no. 1, 2016, p. 42

22.FINKBEINER, W., URSELL, P., DAVIS, R. Autopsy pathology- a manual and atlas, 2nd ed., Saunders Elsevier, Philadelphia, 2009

23.SWAIN, R., KRISHNA, K., SINGH, S.R., BEHERA, C. J Punjab. Acad. Forensic. Med. Toxicol., 12, no. 2, 2012, p. 121

24.LUDWIG, J. Handbook of autopsy practice, 3rd ed., Humana Press, Totowa, New J ersey, 2002

25.SAUKKO, P., KNIGHT, B., Knight's Forensic Pathology, 4th ed., CRC Press. Taylor and Francis Group, Boca Raton, 2016

26.MEKERES, F., BUHAS, C. Rom. J. Leg. Med., 24, no. 1, 2016, p. 11. 27.COMSTOCK, J.P., GARBER, A.J. Ketonuria. In: WALKER, K.H., HALL, D.W., HURST J.W. (Eds.). Clinical Methods: The History, Physical, and Laboratory Examinations. 3rd ed., Butterworths Publishers, Boston, 1990, p. 650.

28.WILLIAMSON, D.H., MELLANBY, J.D. Acetoacetate. In: BERGMEYER, H.B., (Ed.). Methods of enzymatic analysis. Academic Press, New York, 1974, p. 1840.

29.GINGHINA, O., NEGREI, C., HUDITA, A., IOANA-LAVRIC, V., GALATEANU, B., DRAGOMIR, S., BURCEA DRAGOMIROIU, G.T.A., BARCA, M., NITIPIR, C., DIACONU, C.C., PANTEA STOIAN, A.M., IORDACHE, N., BALANESCU, A. Farmacia, 65, no. 6, 2017, p. 947-953. 30.LEIBOVICI, M. Necropsia si semiologia anatomo-clinica. Ed. Medicala, Bucuresti, 1967

31.GILBERT-BARNESS, E., SPICER, D., STEFFENSEN, T. Handbook of Pediatric Autopsy Pathology, 2nd ed., Springer, New York, 2014

32.KLEIN, H.H., PUSCHMANN, S., SCHAPER, J., SCHAPER, W. Virchows Arch., 393, 1981, p. 287

33.DIACONU, C.C., DRAGOI, C.M., BRATU, O.G., NEAGU, T.P., PANTEA STOIAN, A., COBELSCHI, P.C., NICOLAE, A.C., IANCU, M.A., HAINAROSIE, R., STANESCU, A.M.A., SOCEA, B. Farmacia, 66, no. 3, 2018, p. 408-415.

34.DIACONU, C.C., MANEA, M., IANCU, M.A., STANESCU, A.M.A., SOCEA, B., SPINU, D.A., MARCU, D., BRATU, O.G. Rev Chim (Bucharest), 69, no. 5, 2018, p. 1071-1074.

35.SPALDING, R. The identification and characterization of blood and bloodstains. In: JAMES S.H., NORDBY, J.J ., BELL, S. Forensic Science: an introduction to scientific and investigative techniques, 4th ed, CRC Press Taylor and Francis Group, Boca Raton, 2014

36.HARBISON, S.A., FLEMING, R.I. Res. Rep. Forensic Med. Sci., 6, 2016, p. 11

37.GAENSSLEN, R.E. Sourcebook in Forensic Serology, Immunology, and Biochemistry, University of Michigan Library, 1983; p.99 38.GOMEZ, J.A., DIEHL, A.K. Am. J. Med., 92, no. 6, 1992, p. 603. 39.SAKAI, N., IIJ IMA, S., SHIBA, K. Rinsho Byori, 52, no. 11, 2004, p. 877.

$\overline{\text { Manuscript received: } 16.10 .2018}$ 